\title{
Analisis Faktor-Faktor Yang Memengaruhi Angka Gizi Buruk di Indonesia Tahun 2018 Dengan Metode Analisis MCA (Multiple Classification Analysis)
}

\author{
Dena Apriliana \\ Mahasiswa Program Studi D4 Statistika, Polstat STIS, 211810235@stis.ac.id \\ Indri Puspita Devi \\ Mahasiswa Program Studi D4 Statistika, Polstat STIS, 211810342@stis.ac.id \\ M. Latif Al Banna \\ Mahasiswa Program Studi D4 Statistika, Polstat STIS, 211810465@stis.ac.id \\ Rekayati Cahya Adi \\ Mahasiswa Program Studi D4 Statistika, Polstat STIS, 211810553@stis.ac.id \\ Risni Julaeni Yuhan \\ Dosen PolstatSTIS, risnij@stis.ac.id
}

\begin{abstract}
ABSTRAK, Permasalahan mengenai gizi buruk masih menjadi perhatian bersama. Gizi buruk dapat menghambat pertumbuhan dan perkembangan anak. Penuntasan gizi buruk menjadi salah satu tujuan utama dari SDGs. Indonesia sendiri menjadi perhatian dunia berkaitan dengan masih tingginya kasus gizi buruk yang terjadi. Oleh karena itu, peneliti mencoba mencari faktor-faktor yang memengaruhi angka gizi buruk di Indonesia dengan metode analisis MCA (Multiple Classification Analysis). Variabel yang digunakan pada penelitian ini meliputi Angka Prevalensi Gizi Buruk sebagai variabel tak bebas, dan variabel PDRB per Kapita, Persentase Kabupaten/Kota yang Mencapai 80\% Imunisasi Dasar Lengkap pada Bayi, Kunjungan ANC K4, dan Persentase Bayi Usia 6 Bulan yang Mendapat ASI Eksklusif sebagai variabel bebasnya. Hasil dari penelitian ini menunjukkan bahwa variabel Persentase Kabupaten/Kota yang Mencapai 80\% Imunisasi Dasar Lengkap pada Bayi dan variabel Kunjungan ANC K4 secara signifikan memengaruhi Angka Prevalensi Gizi Buruk di Indonesia.
\end{abstract}

Kata Kunci: Prevalensi Gizi Buruk, Imunisasi, ANC K4, MCA

\section{PENDAHULUAN}

Permasalahan mengenai gizi masih menjadi perhatian bersama dunia. Menurut Marimbi yang ditulis kembali oleh Sholikah menerangkan bahwa kekurangan gizi pada masa balita bersifat tidak dapat pulih dan dapat memengaruhi pertumbuhan serta perkembangan otak anak [1]. Pertumbuhan dan perkembangan anak yang terhambat tentunya akan menimbulkan masalah baru. Oleh karenanya gizi anak membutuhkan perhatian khusus dan menjadi salah satu fokus dalam tujuan bersama SDGs.
Sustainable Development Goals atau Tujuan Pembangunan Berkelanjutan merupakan program pembangunan global yang dideklarasikan oleh 193 negara anggota PBB pada tahun 2015. SDGs memiliki tujuh belas tujuan utama serta 169 target yang diharapkan dapat dicapai pada tahun 2030. Salah satu tujuan dari 17 tujuan utama SDGs yaitu mengakhiri kelaparan, mencapai ketahanan pangan dan nutrisi yang lebih baik serta mendukung pertanian yang berkelanjutan. Tahun 2030 ditargetkan untuk mengakhiri malnutrisi serta pada tahun 2025 ditargetkan untuk mengakhiri gizi buruk pada balita, pemenuhan gizi untuk remaja perempuan, wanita hamil, ibu menyusui dan manula [2].

Permasalahan gizi buruk menjadi salah satu fokus pemerintah Indonesia. Pada 2018 terdapat 7,8 juta dari 23 juta balita di Indonesia yang menderita stunting. Hal ini membawa WHO menetapkan Indonesia sebagai negara dengan status gizi buruk. Pemerintah Indonesia menargetkan untuk menurunkan prevalensi stunting dari 37\% pada tahun 2013 menjadi $14 \%$ pada tahun 2024 [3]. Prevalensi gizi buruk di Indonesia pada tahun 2018 adalah sebesar $3,9 \%[4]$.

Berdasarkan uraian masalah di atas peneliti ingin mengetahui faktor-faktor yang memengaruhi angka gizi buruk di Indonesia menggunakan metode MCA (Multiple Classification Analysis). 


\section{TINJAUAN PUSTAKA}

\section{Gizi Buruk dan Faktor-Faktor Penduga Yang Mempengaruhinya}

Gizi buruk diartikan sebagai keadaan kekurangan energi dan protein (KEP) tingkat berat karena kekurangan asupan energi dan protein juga zat gizi mikro dalam waktu yang lama. Gizi buruk ini biasanya dialami oleh anak balita, dengan gejala status gizi sangat kurus atau adanya edema pada punggung kaki sampai seluruh tubuh secara antropometri (BB/TB-PB) adalah $<-3 S D$, dapat terjadi (BB/TB-PB) $>$ $-3 S D$ apabila terdapat edema berat [5].

Menurut Peraturan Menteri Kesehatan No.29 Tahun 2019, yang dimaksud gizi buruk adalah keadaan gizi balita yang ditandai dengan kondisi sangat kurus, disertai atau tidak edema pada kedua punggung kaki, berat badan menurut panjang badan atau berat badan dibanding tinggi badan kurang dari -3 standar deviasi dan/atau lingkar lengan atas kurang dari $11,5 \mathrm{~cm}$ pada anak usia 6-59 bulan [6].

Kasus gizi buruk yang terjadi di suatu wilayah diduga terdapat pengaruh atau sebab dari beberapa variabel-variabel berikut:

\section{a. PDRB per Kapita}

PDRB per Kapita adalah nilai PDRB dibagi jumlah penduduk dalam suatu wilayah per periode tertentu. PDRB per Kapita atas dasar harga berlaku menunjukkan nilai PDB dan PDRB per kepala atau per satu orang penduduk, sedangkan PDRB per Kapita atas dasar harga konstan berguna untuk mengetahui pertumbuhan nyata ekonomi per kapita penduduk suatu negara [7].

Penelitian yang dilakukan oleh Narita Kusumawardhani dan Drajat Martianto pada tahun 2011 menunjukkan bahwa terdapat hubungan negatif antara PDRB per Kapita dengan prevalensi gizi buruk (ditandai dengan nilai slope yang negatif). Hal tersebut memiliki arti semakin tinggi nilai PDRB per Kapita di suatu wilayah maka akan semakin rendah prevalensi gizi buruk di wilayah tersebut begitu pun sebaliknya [8]. b. Imunisasi

Menurut Peraturan Menteri Kesehatan Nomor 12 Tahun 2017 tentang penyelenggaraan imunisasi, seorang anak dinyatakan telah memperoleh imunisasi dasar lengkap apabila telah mendapatkan satu kali imunisasi HB0, satu kali imunisasi BCG, tiga kali imunisasi DPTHB/DPT-HB-HiB, empat kali imunisasi polio atau tiga kali imunisasi IPV, dan satu kali imunisasi campak [9].

Bayi dan balita adalah kelompok yang paling penting untuk mendapatkan imunisasi, karena paling peka terhadap penyakit dan sistem kekebalan tubuh balita masih belum sebaik orang dewasa. Kekebalan tubuh balita akan berkurang dan akan rentan terkena penyakit apabila tidak melakukan imunisasi. Hal ini mempunyai dampak yang tidak langsung dengan kejadian gizi [10].

Menurut penelitian yang dilakukan di Semarang tahun 2012 oleh Dewi Novitasari A, kelengkapan imunisasi merupakan salah satu faktor risiko kejadian gizi buruk balita dengan $(\mathrm{OR}=12,000 ; \mathrm{CI} 95 \%=4,18-34,45)$ [11].

\section{c. ANC K4}

ANC merupakan pelayanan kesehatan kehamilan yang diterima ibu pada masa kehamilan anak terakhir dan diberikan oleh tenaga kesehatan yang kompeten, meliputi dokter (dokter umum dan/atau dokter kandungan), bidan dan perawat. Riwayat ANC adalah jumlah kunjungan ibu hamil berdasarkan cakupan kunjungan yang ada terutama cakupan ANC K4. Cakupan ANC K4 merupakan pelayanan pemeriksaan kesehatan kehamilan oleh tenaga kesehatan yang kompeten dengan frekuensi ANC selama masa kehamilan anak terakhir minimal 4 kali sesuai kriteria minimal 1 1-2 yaitu minimal 1 kali pada masa kehamilan trimester 1, 1 kali pada trimester 2 dan 2 kali pada trimester 3 [4].

Penelitian pada tahun 2012 yang dilakukan oleh Nohora Forero-Ramirez et al, ditemukan bahwa akses perawatan antenatal memiliki efek yang signifikan pada penurunan gizi buruk di Kolumbia dan Peru [12].

\section{d. ASI Ekslusif}

Air Susu Ibu (ASI) merupakan makanan terbaik bagi bayi karena mengandung zat gizi 
paling sesuai untuk pertumbuhan dan perkembangan bayi yang merupakan hak asasi bagi bayi. ASI Eksklusif adalah air susu ibu yang diberikan kepada bayi sejak dilahirkan selama 6 (enam) bulan (0-5 bulan 29 hari), tanpa menambahkan dan/atau mengganti dengan makanan atau minuman lain kecuali obat, vitamin dan mineral. Pemberian ASI Eksklusif dapat mengurangi tingkat kematian bayi yang disebabkan berbagai penyakit (diare dan radang paru), meningkatkan kondisi kesehatan jangka pendek dan panjang, selain itu bermanfaat mempercepat pemulihan bila sakit [7].

Hasil penelitian yang dilakukan oleh Daini Zulmi tahun 2018 menunjukkan bahwa terdapat hubungan yang bermakna antara riwayat pemberian ASI Eksklusif dengan status gizi balita ( $p$-value $=0,000 \mathrm{OR}=8,04)$ [13].

\section{Multiple Classification Analysis}

Multiple Classification Analysis atau yang lebih dikenal dengan MCA merupakan metode alternatif ketika didapati dalam penelitian variabel bebasnya berupa dummy atau kategori sedangkan variabel tidak bebasnya berupa variabel interval/rasio. MCA sangat tepat digunakan sebagai metode analisis ketika variabel bebas berskala kategorik dan variabel tidak bebas berskala rasio/numerik dibanding regresi linier berganda. MCA juga dapat menjelaskan hubungan linear dan non linear antara variabel bebas dan tidak bebas. Namun MCA mensyaratkan data yang dianalisis harus berupa data individu [14]. Metode MCA sangat sesuai dengan yang diharapkan karena metode ini memberikan output yang cocok untuk dipresentasikan langsung dalam laporan [16].

Model yang digunakan pada MCA adalah model aditif (model penambahan) sebagai berikut [14]:

$$
Y_{i j \ldots n}=\bar{Y}+a_{i}+b_{j}+\ldots+\varepsilon_{i j \ldots n}
$$

Keterangan:

$Y_{i j \ldots n}=$ skor pengamatan pada individu pada kategori ke-i dari variabel a, kategori ke-j dari variabel $b$, dan seterusnya

$\bar{Y} \quad=$ grand mean (rata-rata keseluruhan) dari variabel tidak bebas

$a_{i} \quad=$ pengaruh atau efek dari grand mean kategori ke-i dari variabel a $b_{j} \quad=$ pengaruh atau efek dari grand mean kategori ke-j dari variabel b

$\varepsilon_{i j \ldots n}=$ residual bagi individu yang bersesuaian dengan $Y_{i j \ldots n}$

dimana,

$$
\bar{Y}=\frac{\sum_{k=1}^{n} Y_{k}}{n}
$$

$Y_{k}=$ nilai individu ke-x pada variabel dependen

$n=$ banyaknya observasi

Ada beberapa syarat untuk menggunakan metode MCA:

1. Data pada variabel tidak bebas tidak memiliki nilai yang terlalu ekstrim dan tidak ada data outlier.

2. Tidak ada interaksi antara variabel bebasnya.

Data outlier akan memengaruhi nilai ratarata dan variansnya sehingga akan memengaruhi model yang terbentuk. Jika terdapat data yang terlalu ekstrim, maka dapat dilakukan beberapa cara yaitu dengan membuangnya atau melakukan transformasi data [15].

Statistik Eta ( $)$ digunakan untuk mengukur besarnya pengaruh dari variabel bebas ke-i terhadap variabel tidak bebas. Statistik Eta juga mengukur besarnya hubungan sebelum dikontrol oleh variabel lain. Kemudian untuk statistik Beta $(\beta)$ digunakan untuk mengukur besarnya pengaruh dari variabel bebas ke-i terhadap variabel tidak bebas setelah dikontrol oleh variabel lain [17].

\section{METODOLOGI}

Data yang digunakan pada penelitian ini adalah data sekunder yang bersumber dari Riset Kesehatan Dasar (Riskesdas) tahun 2018 dan publikasi BPS RI pada tahun 2018. Unit observasi yang digunakan 34 Provinsi di Indonesia. Program komputer untuk mendukung proses penelitian menggunakan software statistik yaitu SPSS 25. Variabel yang digunakan dalam penelitian ini adalah angka gizi buruk pada 34 Provinsi di Indonesia dengan variabel yang berhubungan dengan situasi sosial ekonomi dan kesehatan masyarakat yang berjumlah 4 variabel, dengan masing-masing variabel bebas bersifat kategorik, sedangkan untuk variabel tidak bebas bersifat numerik, yaitu sebagai berikut:

Y $=$ Prevalensi Gizi Buruk

$X_{1} \quad=$ PDRB per Kapita 
$X_{2} \quad=$ Persentase Kabupaten/Kota yang Mencapai 80\% Imunisasi Dasar Lengkap pada Bayi

$X_{3} \quad=$ Kunjungan ANC K4

$X_{4} \quad=$ Persentase Bayi Usia Kurang dari 6 Bulan yang Mendapat ASI Eksklusif.

Model MCA banyak digunakan untuk mencari solusi yang terkait dengan data-data sosial kependudukan yang terbatas dengan variabel yang berskala kategori. MCA juga merupakan teknik untuk mengetahui hubungan antar beberapa variabel bebas dengan satu variabel tidak bebas, serta mencari efek dari masing-masing variabel bebas tersebut dari sebelum disesuaikan dengan variabel bebas lainnya ke sesudah disesuaikan dengan variabel lain. Tahapan yang dilakukan pada analisis ini yaitu:

1. Mencari data yang dibutuhkan dan mengidentifikasi jenis data yang akan digunakan.

2. Melakukan observasi apakah variabel tidak bebas memiliki nilai ekstrim (apabila ada).

3. Mencari outlier pada masing-masing variabel (apabila ada).

4. Melakukan pengujian model (uji simultan dan uji parsial) serta menentukan hipotesis yang akan dilakukan dengan tingkat signifikansi sebesar $5 \%$.

5. Melakukan pengecekan ada tidaknya interaksi antar variabel bebasnya. Uji signifikasi F pada pola interaksi antar variabel bebas yang terbentuk.

6. Mencari nilai eta $(\eta)$ dan beta $(\beta)$.

7. Mencari besarnya pengaruh variabel bebas terhadap variabel tidak bebasnya dapat diketahui dari nilai koefisien determinasi $\left(\mathrm{R}^{2}\right)$.

\section{PEMBAHASAN}

\section{Analisis Deskriptif}

Provinsi dengan Angka Prevalensi Gizi Buruk pada Balita terendah adalah Provinsi Bali, DKI Jakarta, dan Kalimantan Utara. Sedangkan provinsi dengan Angka Prevalensi Gizi Buruk pada Balita tertinggi di Indonesia adalah Provinsi Maluku, Nusa Tenggara Timur dan Gorontalo.

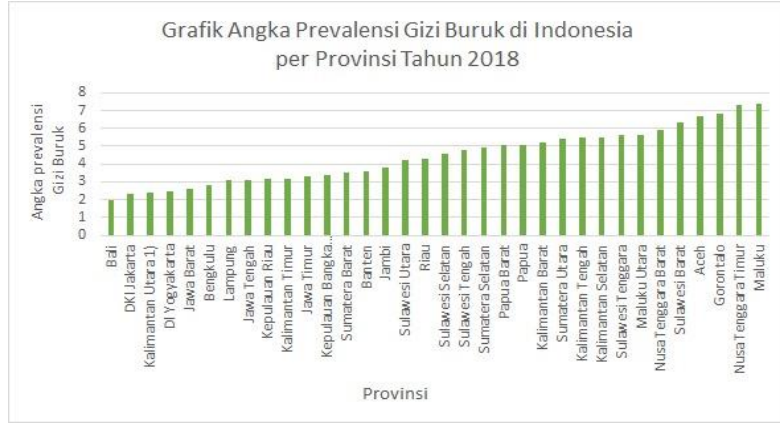

Gambar 1. Grafik Angka Prevalensi Gizi Buruk pada Balita di Indonesia per Provinsi Tahun 2018

Analisis MCA dapat memberikan hasil yang baik ketika variabel tidak bebas bersifat simetris atau berdistribusi normal. Data Angka Prevalensi Gizi Buruk pada Balita di Indonesia sudah memenuhi asumsi normalitas, sehingga dapat digunakan untuk prosedur MCA.

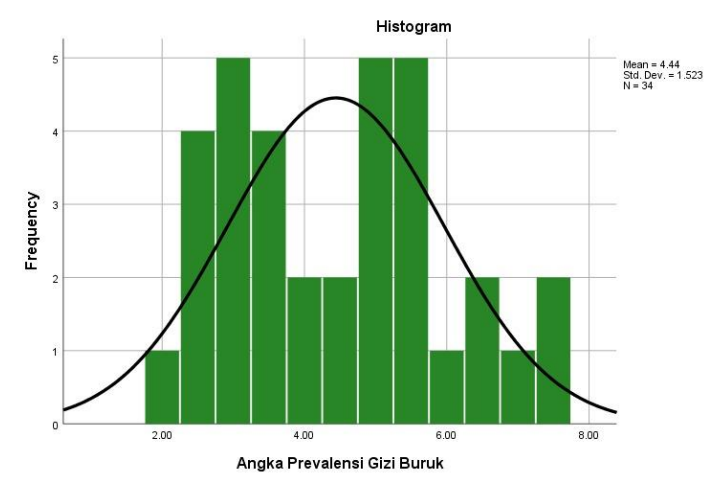

Gambar 2. Grafik Histogram Sebaran Angka Prevalensi Gizi Buruk pada Balita Menurut Provinsi di Indonesia Tahun 2018

Persentase Kabupaten/Kota yang Mencapai 80\% Imunisasi Dasar Lengkap pada bayi dikategorikan menggunakan median. Median dari data Persentase Kabupaten/Kota yang Mencapai 80\% Imunisasi Dasar Lengkap pada Bayi per provinsi di Indonesia adalah 78,05\%. Selanjutnya Kunjungan ANC K4 dikategorikan menggunakan median dengan median sebesar 67,25\%. Variabel Persentase Bayi Usia Kurang dari 6 Bulan yang Mendapat ASI Eksklusif dikategorikan menggunakan median dengan median sebesar 44,35\%.

Berdasarkan gambar 3, PDRB per Kapita Provinsi di Indonesia sebagian besar masuk ke 
dalam kategori low-lower middle income, Kategori low-lower middle income memiliki pendapatan dibawah \$4.045. Sedangkan kategori upper middle-high income memiliki pendapatan diatas \$4.046 [18].

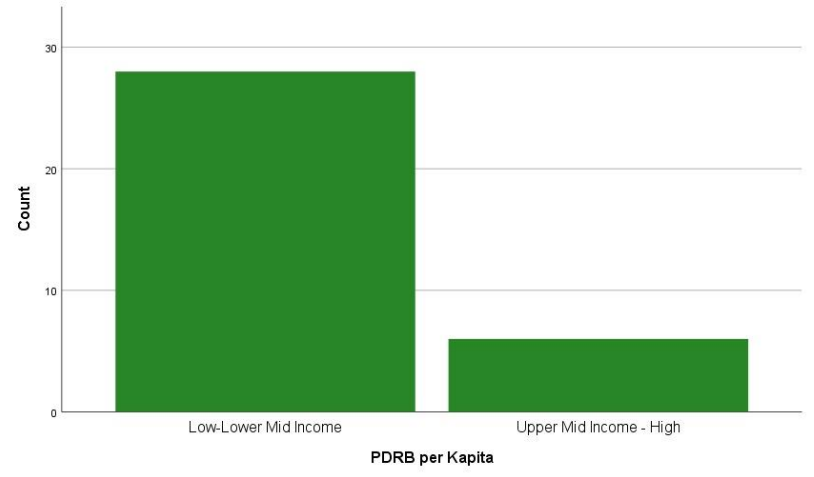

Gambar 3. Grafik PDRB per Kapita Menurut Provinsi di Indonesia Tahun 2018

\section{Analisis Inferensia}

Sebelum melakukan analisis MCA, terlebih dahulu dilakukan identifikasi klasifikasi

data yang digunakan. Variabel tak bebas (Y) yang digunakan dalam penelitian ini adalah Angka Prevalensi Gizi Buruk di setiap provinsi di Indonesia. Kemudian untuk variabel bebas (X) yang digunakan adalah PDRB per Kapita, Persentase Kabupaten/Kota yang Mencapai 80\% Imunisasi Dasar Lengkap pada Bayi, Kunjungan ANC K4, dan Persentase Bayi Usia Kurang 6 Bulan yang Mendapat ASI Eksklusif. Berikut merupakan klasifikasi pada masing-masing variabel yang digunakan.

Tabel 1. Klasifikasi Variabel

\begin{tabular}{|c|c|c|c|}
\hline Variabel & Nama & Kategori & Kode \\
\hline $\mathrm{Y}$ & Angka Prevalensi Gizi Buruk Balita & - & - \\
\hline \multirow[t]{2}{*}{$X_{1}$} & PDRB per Kapita & $\begin{array}{l}\leq \text { lower } \\
\text { Middle } \\
\text { Income }\end{array}$ & 1 \\
\hline & & $\begin{array}{l}\text { > lower } \\
\text { Middle } \\
\text { Income }\end{array}$ & 2 \\
\hline \multirow[t]{2}{*}{$X_{2}$} & $\begin{array}{l}\text { Persentase Kabupaten/Kota yang } \\
\text { Mencapai } 80 \% \text { Imunisasi Dasar Lengkap }\end{array}$ & $\leq$ median & 1 \\
\hline & pada Bayı & $>$ median & 2 \\
\hline \multirow[t]{3}{*}{$X_{3}$} & Kunjungan ANC K4 & $\leq$ median & 1 \\
\hline & & $>$ median & 2 \\
\hline & & $\leq$ median & 1 \\
\hline
\end{tabular}

$X_{4}$ Persentase Bayi Usia Kurang dari 6 Bulan > median 2 yang Mendapat ASI Eksklusif

Setelah melakukan klasifikasi pada setiap variabel, kemudian dilakukan Uji ANOVA yang bertujuan untuk mengetahui apakah variabel tak bebas secara simultan maupun parsial dapat memengaruhi Angka Prevalensi Gizi Buruk. Hipotesis yang digunakan pada uji simultan yaitu:

$H_{0}$ : tidak ada pengaruh variabel bebas (X) terhadap Angka Prevalensi Gizi Buruk Balita

$H_{1}$ : minimal ada satu variabel bebas $(\mathrm{X})$ yang memengaruhi Angka Prevalensi Gizi Buruk Balita

Sedangkan untuk uji parsial, hipotesis yang digunakan adalah:

$H_{0}$ :variabel bebas $(\mathrm{X})$ ke-i tidak memengaruhi Angka Prevalensi Gizi Buruk Balita

$H_{1}$ :variabel bebas (X) ke-i memengaruhi Angka

Prevalensi Gizi Buruk Balita

Dengan $\mathrm{i}=1,2,3,4$

MCA mensyaratkan tidak adanya interaksi diantara variabel bebasnya. Oleh karenanya sebelum melakukan Analisis MCA, terlebih dahulu dilakukan untuk semua variabel bebas termasuk interaksinya dan didapatkan hasil Uji ANOVA untuk Interaksi antar variabel sebagai berikut

Tabel 2. Uji ANOVA Interaksi

\begin{tabular}{|c|c|c|c|c|c|}
\hline & $\begin{array}{l}\text { Sum of } \\
\text { Squares }\end{array}$ & $\begin{array}{l}d \\
f\end{array}$ & $\begin{array}{c}\text { Mean } \\
\text { Squar } \\
\mathrm{e}\end{array}$ & $\mathrm{F}$ & Sig. \\
\hline (Combined) & 2,616 & 6 & 0,436 & $\begin{array}{c}0,42 \\
6\end{array}$ & $\begin{array}{c}0,85 \\
4\end{array}$ \\
\hline $\begin{array}{l}\text { kode_PDRB * } \\
\text { Kode_K4 }\end{array}$ & 0,082 & 1 & 0,082 & $\begin{array}{c}0,08 \\
0\end{array}$ & $\begin{array}{c}0,78 \\
0\end{array}$ \\
\hline $\begin{array}{l}\text { kode_PDRB * } \\
\text { Kode_ASI }\end{array}$ & 0,840 & 1 & 0,840 & $\begin{array}{c}0,82 \\
0\end{array}$ & $\begin{array}{c}0,37 \\
5\end{array}$ \\
\hline $\begin{array}{l}\text { kode_PDRB * } \\
\text { Kode_Imunisa } \\
\text { si }\end{array}$ & 1,260 & 1 & 1,260 & $\begin{array}{c}1,23 \\
0\end{array}$ & $\begin{array}{c}0,27 \\
9\end{array}$ \\
\hline $\begin{array}{l}\text { Kode_K4 * } \\
\text { Kode_ASI }\end{array}$ & 0,086 & 1 & 0,086 & $\begin{array}{c}0,08 \\
4\end{array}$ & $\begin{array}{c}0,77 \\
4\end{array}$ \\
\hline $\begin{array}{l}\text { Kode_K4 * } \\
\text { Kode_Imunisa } \\
\text { si }\end{array}$ & 0,018 & 1 & 0,018 & $\begin{array}{c}0,01 \\
8\end{array}$ & $\begin{array}{c}0,89 \\
6\end{array}$ \\
\hline $\begin{array}{l}\text { Kode_ASI * } \\
\text { Kode_Imunisa } \\
\text { si }\end{array}$ & 0,064 & 1 & 0,064 & $\begin{array}{c}0,06 \\
3\end{array}$ & $\begin{array}{c}0,80 \\
4\end{array}$ \\
\hline
\end{tabular}

Dari Tabel 2. tersebut dapat diketahui bahwa uji parsial untuk interaksi menunjukkan Hasil p-value yang semuanya diatas 0,05 . Hal tersebut menunjukkan bahwa tidak adanya 
interaksi yang terjadi untuk semua variabel bebas yang diujikan. Sehingga salah satu asumsi MCA yang mensyaratkan tidak adanya interaksi antar variabel bebas sudah terpenuhi. Karena terpenuhinya asumsi tersebut maka analisis MCA dapat dilakukan.

Berdasarkan tabel 3., pada uji simultan didapatkan keputusan Tolak $H_{0}$ karena nilai signifikansi ( $p$-value) model $<0,05$ sehingga dapat ditarik kesimpulan bahwa dengan tingkat signifikansi $5 \%$, sudah cukup bukti untuk

Tabel 3. Hasil Uji ANOVA ANOVA $^{\mathrm{a}}$

\begin{tabular}{|c|c|c|c|c|c|c|}
\hline & & \multicolumn{5}{|c|}{ Experimental Method } \\
\hline & & $\begin{array}{c}\text { Sum of } \\
\text { Squar } \\
\text { es }\end{array}$ & df & $\begin{array}{c}\text { Mean } \\
\text { Square }\end{array}$ & $\mathrm{F}$ & Sig. \\
\hline \multirow{5}{*}{$\begin{array}{l}\text { Main } \\
\text { Effec } \\
\text { ts }\end{array}$} & (Combined) & 50,37 & 4 & 12,593 & 13,953 & 0 \\
\hline & kode_PDRB & 1,76 & 1 & 1,76 & 1,95 & $\begin{array}{c}0,17 \\
3\end{array}$ \\
\hline & $\underset{\text { asi }}{\text { Kode_Imunis }}$ & 7,372 & 1 & 7,372 & 8,168 & $\begin{array}{c}0,00 \\
8\end{array}$ \\
\hline & Kode_K4 & 10,534 & 1 & 10,534 & 11,673 & $\begin{array}{c}0,00 \\
2\end{array}$ \\
\hline & kode_ASI & 0,114 & 1 & 0,114 & 0,127 & $\begin{array}{c}0,72 \\
4 \\
\end{array}$ \\
\hline \multicolumn{2}{|r|}{ Model } & 50,37 & 4 & 12,593 & 13,953 & 0 \\
\hline \multicolumn{2}{|r|}{ Residual } & 26,172 & 29 & 0,902 & & \\
\hline \multicolumn{2}{|r|}{ Total } & 76,542 & 33 & 2,319 & & \\
\hline
\end{tabular}

menyatakan bahwa minimal terdapat satu variabel diantara PDRB per Kapita, Persentase Kabupaten/Kota yang Mencapai 80\% Imunisasi Dasar Lengkap pada Bayi, Kunjungan ANC K4, dan Persentase Bayi Usia Kurang dari 6 Bulan yang Mendapat ASI Eksklusif yang memengaruhi Angka Prevalensi Gizi Buruk di Indonesia.

Pada tabel yang sama juga didapatkan hasil Uji Signifikansi Parsial. Berdasarkan pada uji tersebut, diperoleh bahwa variabel Persentase Kabupaten/Kota yang Mencapai 80\% Imunisasi Dasar Lengkap pada Bayi dan variabel Kunjungan ANC K4, secara signifikan memengaruhi Angka Prevalensi Gizi Buruk dikarenakan nilai signifikansi parameter pada kedua variabel tersebut $<0,05$. Sedangkan untuk variabel PDRB per Kapita dan Persentase Bayi Usia Kurang dari 6 Bulan yang Mendapat ASI Eksklusif dapat dikatakan tidak memengaruhi Angka Prevalensi Gizi Buruk karena nilai signifikansi parameter pada kedua variabel tersebut $>0,05$.

Setelah dilakukan uji ANOVA, maka langkah selanjutnya yaitu mencari parameter model MCA yang terbentuk. Berdasarkan pada Tabel 3. Uji ANOVA, maka variabel-variabel yang signifikan digunakan untuk membuat model MCA. Model MCA yang terbentuk adalah sebagai berikut.

$$
\text { Gizi Buruk }_{i j k}=\bar{Y}+\text { Imunisasi }_{i}+K 4_{j}
$$

Kemudian mencari grand mean yaitu sebagai berikut.

Tabel 4. Parameter Model MCA

\begin{tabular}{llrr}
\hline Variabel & Kategori & $\begin{array}{l}\text { Predicted } \\
\text { Mean }\end{array}$ & $\begin{array}{l}\text { Deviasi } \\
\text { MCA }\end{array}$ \\
\hline Imunisasi & 1 & 5,012 & 0,57078 \\
& 2 & 3,8704 & $-0,57078$ \\
ANC K4 & 1 & 5,1508 & 0,70966 \\
& 2 & 3,7315 & $-0,70966$ \\
& Grand & & \\
& mean & 4,441175 & \\
\hline
\end{tabular}

Berdasarkan Tabel 4., diperoleh model MCA yang terbentuk untuk Angka Prevalensi Gizi Buruk yaitu:

$$
\text { Gizi Buruk }_{i j k}=4,4412+\text { Imunisasi }_{i}+K 4_{j}
$$

Masing-masing kategori pada setiap variabel bebas memiliki parameter yang berbedabeda. Pada kategori pertama variabel Persentase Kabupaten/Kota yang Mencapai $80 \%$ Imunisasi Dasar Lengkap pada Bayi memiliki parameter sebesar 0,57078 yang dapat diartikan bahwa provinsi yang mencapai Imunisasi Dasar Lengkap pada Bayi pada kategori pertama memiliki kecenderungan meningkatkan Angka Prevalensi Gizi Buruk sebesar 0,57078\%. Sedangkan besarnya parameter untuk kategori kedua adalah $-0,57078$ yang artinya provinsi yang mencapai $80 \%$ Imunisasi Dasar Lengkap pada Bayi pada kategori kedua cenderung menurunkan Angka Prevalensi Gizi Buruk sebesar 0,57078\%. Pada kategori pertama variabel Kunjungan ANC K4 memiliki parameter sebesar 0,70966 yang artinya Kunjungan ANC K4 pada kategori pertama cenderung meningkatkan Angka Prevalensi Gizi Buruk pada provinsi tersebut sebesar 0,70966\%. Sedangkan parameter untuk kategori kedua sebesar -0,70966 yang artinya Kunjungan ANC K4 pada kategori kedua cenderung menurunkan Angka Prevalensi Gizi Buruk sebesar 0,70966\%. Berdasarkan Hal tersebut dapat diketahui bahwa Persentase Kabupaten/Kota 
yang Mencapai 80\% Imunisasi Dasar Lengkap pada Bayi dan Kunjungan ANC K4 memiliki pengaruh negatif terhadap Angka Prevalensi Gizi Buruk atau dalam kata lain dapat diketahui bahwa semakin tinggi nilai kedua variabel tersebut akan menurunkan Angka Prevalensi Gizi Buruk.

Berdasarkan diagram aditif tersebut, provinsi yang memiliki Angka Prevalensi Gizi

\begin{tabular}{|c|c|c|c|c|c|}
\hline & \multirow{2}{*}{\multicolumn{2}{|c|}{$\begin{array}{c}\text { Grand Mean } \\
4,4412 \\
\end{array}$}} & \multirow[b]{3}{*}{+} & \\
\hline & & & & & \\
\hline $\begin{array}{c}\text { Kategori } \\
1\end{array}$ & \multirow[t]{2}{*}{+} & \multicolumn{2}{|c|}{$80 \%$ Imunisasi } & & $\begin{array}{c}\text { Kategori } \\
2\end{array}$ \\
\hline 5,012 & & 9,4532 & 8,3116 & & 3,8704 \\
\hline
\end{tabular}

\begin{tabular}{|c|c|c|c|}
\hline $\begin{array}{c}\text { Kategori } \\
1\end{array}$ & + & $\begin{array}{c}80 \% \text { Imunisasi } \\
+ \text { ANC K4 }\end{array}$ & $+\begin{array}{c}\text { Kategori } \\
2\end{array}$ \\
\hline 5,1508 & & 14,604 & 12,0431 \\
\cline { 3 - 4 }
\end{tabular}

Gambar 3. Diagram Aditif

buruk pada balita tertinggi adalah provinsi dengan Persentase Kabupaten/Kota yang Mencapai 80\% Imunisasi Dasar Lengkap pada Bayi kategori 1 atau kurang dari median dengan Kunjungan ANC K4 kategori 1 atau kurang dari median.

Tabel 5. Statistik Eta dan Beta Factor Summary ${ }^{\mathrm{a}}$

\begin{tabular}{|c|c|c|c|}
\hline & & \multirow[b]{2}{*}{ Eta } & Beta \\
\hline & & & Adjusted for Factors \\
\hline \multirow{4}{*}{ GB } & kode_PDRB & 0,316 & 0,164 \\
\hline & Kode_Imunisasi & 0,643 & 0,380 \\
\hline & Kode_K4 & 0,737 & 0,473 \\
\hline & kode_ASI & 0,318 & 0,041 \\
\hline
\end{tabular}

Berdasarkan tabel 5, dapat diketahui besarnya nilai Eta dan Beta. Melalui nila Eta dan Beta dapat diketahui pengaruh dari masingmasing variabel bebas terhadap variabel tidak bebas. Variabel yang paling berpengaruh terhadap Angka Prevalensi Gizi Buruk pada Balita adalah variabel Kunjungan ANC K4 yang ditunjukkan dengan nilai Eta terbesar dari seluruh variabel yaitu sebesar 0,737 . Kemudian variabel yang paling berpengaruh selanjutnya berturut-turut yaitu Persentase Kabupaten/Kota yang Mencapai 80\% Imunisasi Dasar Lengkap pada Bayi, Persentase Bayi Usia Kurang dari 6 Bulan yang Mendapat ASI Eksklusif, dan PRDB per Kapita.

Dari Tabel 6. dapat diketahui bahwa Koefisien $\mathrm{R}^{2}$ yang didapatkan adalah sebesar 0,658 yang artinya bahwa total keragaman dari variabel Angka Prevalensi Gizi Buruk yang dapat dijelaskan oleh variabel PDRB per Kapita, Persentase Kabupaten/Kota yang Mencapai 80\% Imunisasi Dasar Lengkap pada Bayi, Kunjungan

Tabel 6. Koefisien Determinasi

Model Goodness of Fit

\begin{tabular}{ccc}
\hline & $\mathrm{R}$ & $\mathrm{R}$ Squared \\
\hline $\begin{array}{c}\text { GB by kode_PDRB, } \\
\text { Kode_Imunisasi, }\end{array}$ & 0,811 & 0,658
\end{tabular}

Kode_K4, kode_ASI

ANC K4, dan Persentase Bayi Usia Kurang dari 6 Bulan yang Mendapat ASI Eksklusif sebesar $65,8 \%$ dan sisanya dijelaskan oleh variabel yang lain. Nilai tersebut sudah dikatakan cukup baik karena nilainya lebih dari 50\% sehingga model tersebut cukup baik untuk digunakan dalam analisis.

\section{KESIMPULAN}

Berdasarkan hasil yang diperoleh pada analisis MCA, maka dapat diketahui bahwa variabel Persentase Kabupaten/Kota yang Mencapai 80\% Imunisasi Dasar Lengkap pada Bayi dan variabel Kunjungan ANC K4 secara signifikan memengaruhi Angka Prevalensi Gizi Buruk. Kedua Variabel tersebut berpengaruh negatif terhadap Angka Prevalensi Gizi Buruk. Selain itu, diperoleh juga parameter MCA yang terbentuk untuk Angka Prevalensi Gizi Buruk serta mendapatkan statistik Eta dan Beta yang terkait antara variabel tidak bebas dengan variabel bebasnya. Model tersebut memiliki korelasi yang cukup baik untuk menggambarkan keragaman prevalensi Gizi Buruk.

\section{DAFTAR PUSTAKA}

[1] Anik Sholikah dkk. 2017. "Faktor-faktor yang Berhubungan dengan Status Gizi Balita di Perdesaan dan Perkotaan". Public Health Perspective Journal 2 (1). 
http://journal.unnes.ac.id/sju/index.php/ph pj.

[2] Sustainable Development Goals. (2017). "Sustainable Development Goals". Retrieved Juni 3, 2020, from sdgs2030indonesia.org:https://www.sdg20 30indonesia.org.

[3] Sugianto, D. (2020, 5 Agustus). "Jokowi Ungkap 10 Provinsi dengan Angka Gizi Buruk Tertinggi". Retrieved Juni 3, 2020, from detik.com: https://finance.detik.com/beritaekonomi-bisnis/d-5120947/jokowi-ungkap-

10-provinsi-dengan-angka-gizi-buruktertinggi.

[4] Kementrian Kesehatan RI. (2019). "Laporan Nasional Riskesdas 2018". Jakarta: Lembaga Penerbit Badan Penelitian dan Pengembangan Kesehatan.

[5] Pakar Gizi Indonesia. 2017. Ilmu Gizi: Teori dan Aplikasi. Jakarta. Buku Kedokteran EGC.

[6] Kementrian Kesehatan. 2019. Peraturan Menteri Kesehatan Republik Indonesia Nomor 29 Tahun 2019 tentang Penanggulangan Masalah Gizi Bagi Anak Akibat Penyakit.

[7] Badan Pusat Statistik. Dipetik Juni 4, 2021, dari SIRuSa: https://sirusa.bps.go.id

[8] Kusumawardhani, N., \& Martianto, D. (2011). Kaitan Antara Prevalensi Gizi Buruk dengan PDRB per Kapita dan Tingkat Kemiskinan serta Estimasi Kerugian Ekonomi Akibat Gizi Buruk pada Balita di Berbagai Kabupaten/Kota di Pulau Jawa dan Bali. Jurnal Gizi Dan Pangan, 6(1),

[9] Kementrian Kesehatan. 2017. Peraturan Menteri Kesehatan Republik Indonesia Nomor 12 Tahun 2017 tentang Penyelenggaraan Imunisasi.

[10] Hidayat AAA. 2008. Pengantar Ilmu Kesehatan Anak untuk Pendidikan Kebidanan. Jakarta:Salemba. Medika.

[11] A, Dewi Novitasari. 2012. Faktor-Faktor Risiko Kejadian Gizi Buruk pada Balita yang Dirawat di Rsup Dr. Kariadi Semarang. Universitas Diponegoro.

[12] Ramirez, N.F, et al. Child Malnutrition and Antenatal Care: Evidence from three Latin American countries. ISS 2012; 536.
[13] Zulmi, Daini. 2018. Hubungan Antara Pemberian ASI Eksklusif dengan Status Gizi Balita di Wilayah Kerja Puskesmas Warunggunung Tahun 2018. Medikes (Media Informasi Kesehatan) Vol 6 No. 1.

[14] Sugiarto. 2008. Multiple Classification Analysis (MCA)sebagai Metode Alternatif Analisis Data untuk Variabel Bebas yang Kategori. Jurnal Statistika Vol 6 No.2. Hal 85-93: Universitas Muhammadiyah Surakarta.https://jurnal.unimus.ac.id/index $. \mathrm{php} / \mathrm{statistik/article/view/4312/3991}$

[15] Cohen, Jacob et all. 2002. Applied Multiple Regression-Correlation Analysis for the Behavioral Sciences, 3rd Edition: Lawrence Erlbaum Associates, Inc.

[16] Lolle, Henrik. 2008. Multiple Classification Analysis (MCA): Unfortunetly, a Nearly Forgotten Method For Doing Linear Regression With Categorical Variabel. Aalborg University.

[17] Susel, A. 2011. Multiple Classification Analysis. Theory and Aplication to Demography. Folia Economica.

[18] World Bank. (2021, June 9). World Bank. Retrieved from www.worldbank.org: www.worldbank.org 